\title{
Migrantes dos espaços (sertão, memória e nação)
}

\author{
Sandra Guardini Teixeira Vasconcelos \\ Universidade de São Paulo
}

\author{
"Riobaldo (...) é apenas o Brasil". \\ (Guimarães Rosa em entrevista a Gunter Lorenz)
}

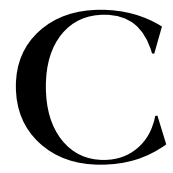

om a força que as imagens têm de construir sentidos, Euclides da Cunha conformou no nível da linguagem, ao descrever o sertanejo como um Hércules-Quasímodo, as tensões que iriam marcar a caracterização desse tipo brasileiro a partir de Os sertões (1902). Com Euclides, ganhava complexidade e densidade a figura que José de Alencar desenhara em O sertanejo (1875), dentro de seu projeto literário de mapear as regiões brasileiras e pintar seus tipos. Ao herói romântico que Alencar criara como um modelo de força, virilidade e virtude veio sobrepor-se praticamente novo persona-gem, cuja cicatriz de origem se configuraria sob o signo da antinomia e da contradição. Forjado na adversidade, porque obrigado à difícil convivência com a paisagem agreste, a seca e os desastres naturais, mas "sub-raça" porque produto de múltiplos cruzamentos, ${ }^{1} \mathrm{O}$ sertanejo surge em Euclides como uma mescla de nobreza e força, de um lado, e primitivismo e rudeza, de outro, um ser não decaído, mas retrógrado, porque mais infenso ao impacto da civilização.

O sertanejo é, antes de tudo, um forte. Não tem o raquitismo exaustivo dos mestiços neurastênico do litoral.

A sua aparência, entretanto, ao primeiro lance de vista, revela o contrário. Falta-lhe a plástica impecável, o desempenho, a estrutura corretíssima das organizações atléticas.

\footnotetext{
${ }^{1}$ Sobretudo entre o branco e o índio, e um pouco do negro.
} 
É desgracioso, desengonçado, torto. Hércules-Quasímodo, reflete no aspecto a fealdade típica dos fracos. $\mathrm{O}$ andar sem firmeza, sem aprumo, quase gigante e sinuoso, aparenta a translação de membros desarticulados. Agrava-o a postura normalmente abatida, num manifestar de displicência que lhe dá um caráter de humildade deprimente. A pé, quando parado, recosta-se invariavelmente ao primeiro umbral ou parede que encontra; a cavalo, se sofreia o animal para trocar duas palavras com um conhecido, cai logo sobre um dos estribos, descansando sobre a espenda da sela. (...)

É o homem permanentemente fatigado.

Reflete a preguiça invencível, a atonia muscular perene, em tudo: na palavra remorada, no gesto contrafeito, no andar desaprumado, na cadência langorosa das modinhas, na tendência constante à imobilidade e à quietude.

Entretanto, toda essa aparência de cansaço ilude. (Os sertões, 179-180)

As célebres antíteses que consagraram o sertanejo, na pena euclidiana, como guerreiro combativo e valente mas feio e mirrado "(...) da figura vulgar do tabaréu canhestro, reponta, inesperadamente, o aspecto dominador de um titã acobreado e potente, num desdobramento surpreendente de força e agilidade extraordinárias" (Os sertões, 170) -, se marcaram as contradições de um intelectual orientado pelas teorias raciais de seu tempo, também demonstram o quanto a capacidade de resistência desses homens em situações muito adversas acabou por ganhar a admiração do escritor, impactado pela tragédia que se descortinou diante de seus olhos e da qual foi testemunha e repórter. A condenação inicial da "sub-raça" dá lugar então à denúncia da violência, do atraso secular, do abandono social e do isolamento a que foram submetidas essas populações pelo "litoral civilizado" e a conclusão, nas últimas páginas do livro, é no mínimo potente: o sertanejo é a rocha viva da nossa raça, constitui o cerne de uma nacionalidade. Espaço da barbárie e do atraso cultural, os sertões surgiam, assim, como o lugar onde iriam se desenvolver a verdadeira nacionalidade e o brasileiro do futuro, ao passo que o sertanejo ganhava estatuto de personagem definitivo nas letras nacionais.

Com seu monumental ensaio literário-sociológico-históricoetnográfico, Euclides da Cunha expunha as cicatrizes de um Brasil 
cindido e forjava a matriz dualista de interpretação da sociedade brasileira, dando voz aos dilaceramentos de um país em que o processo de modernização nunca se deu de forma homogênea. De quebra, deixava para a literatura brasileira imagens de uma força ímpar, como a do sertanejo-centauro ou a dos peregrinos de passo tardo, que iriam marcar um modo de ver essas populações rurais, sempre deixadas à margem do progresso e dos benefícios do desenvolvimento.

A idéia do sertão como atraso não era nova. O "sartaam" nomeado pela primeira vez por Pero Vaz de Caminha e descrito como o espaço para dentro das praias que se podia apenas vislumbrar e imaginar, mas não enxergar, ${ }^{2}$ não indicava, no Brasil colonial dos séculos XVI e XVII, uma delimitação espacial precisa e representava, no nível do imaginário,

(...) o território do vazio, o domínio do desconhecido, o espaço ainda não preenchido pela colonização. É, por isso, o mundo da desordem, domínio da barbárie, da selvageria, do diabo. Ao mesmo tempo, se conhecido, pode ser ordenado através da ocupação e da colonização, deixando de ser sertão para constituir-se em região colonial. ${ }^{3}$

Nenhum traço do locus amoenus, portanto, do lugar aprazível, idílico e tranqüilo que iria se tornar para alguns românticos como

\footnotetext{
${ }^{2}$ Ver $A$ carta de Pero Vaz de Caminha: "Pelo sertão nos pareceu, [esta terra] vista do mar, muito grande, porque, a estender olhos, não podíamos ver senão terra com arvoredos, que nos parecia muito longa". (CORTESÃO, 1999). Walnice Nogueira Galvão, reportando-se a estudo de Gustavo Barroso, explica que a palavra sertão "nada tinha a ver com a noção de deserto (aridez, secura, esterilidade) mas sim com a de "interior', de distante da costa". Sua etimologia é referida a muceltão, ou seja locus mediterraneus, "um lugar que fica no centro ou no meio das terras". Significando "mato", na África Portuguesa, a corruptela certão teve seu sentido ampliado depois para "mato longe da costa”. (GALVÃO, 2001).

${ }^{3}$ MADER, Maria Elisa S. O vazio: o sertão no imaginário da colônia nos séculos XVI e XVII. Dissertação (Mestrado em História). Rio de Janeiro, PUC, 1995, p. 13, apud LIMA, 1999, p. 58.
} 
Bernardo Guimarães ou o próprio Alencar. ${ }^{4}$ Pelo contrário, são o aspecto atormentado da paisagem e a figura contraditória de seu habitante que vão encontrar formulação no âmbito literário, a partir de Euclides, desenhando de maneira definitiva a face desse lugar que está em toda parte:

Sertão é, para Euclides, tudo aquilo que está fora da escrita da história e do espaço da civilização: terra de ninguém, lugar da inversão de valores, da barbárie e da incultura. São territórios misteriosos, fora da história e da geografia, que não foram mapeados de forma sistemática. ${ }^{5}$

Um sertão, muitos sertões: interior longínquo e despovoado, ou habitado por uma raça mestiça; lugar da economia agrária e subdesenvolvida em contraste com a economia industrial e mais desenvolvida da metrópole; espaço dos laços comunitários, com outros usos e costumes e formas de pensamento mais míticas; lugar do poder de coronéis e do desamparo de camaradas; desde as entradas e bandeiras, lugar de origem histórica e genuína; local de vida heróica ou trágica, saudável e autêntica, ou de vida identitária. Ou, como o via Quaderna, do alto da janela da Cadeia, na sua tripla face, de Paraíso, Purgatório e Inferno: ${ }^{6}$ palco edênico de amantes ou do Luar do Sertão; solo calcinado onde se desenrolam os dramas da seca e onde impera a violência social; lugar de penitência e travessia, signo da passagem e símbolo da condição humana.

Mais do que região determinada e delimitada, o sertão se configura como uma idéia e a sua diferença em relação ao litoral se define antes pelo contraste entre fases históricas diversas do que por diferenças geográficas significativas. Lido nessa chave, importaria mais a contraposição ou superposição, em um mesmo território, de diferentes temporalidades, camadas temporais distintas mas coetâneas do que a distância a separar interior e litoral, vistos como

\footnotetext{
${ }^{4}$ Ver O ermitão de Muquém (1869), de Bernardo Guimarães, e O sertanejo (1875) de José de Alencar.

${ }^{5}$ VENTURA, 1998. p. 65.

${ }^{6}$ SUASSUNA, 1973. p. 3.
} 
imagens espaciais e simbólicas de dois tipos de organização social e cultural. Daí a persistência da matriz dualista de interpretação da sociedade brasileira, calcada na dicotomia entre a civilização litorânea e a civilização do interior.

Se a tese dos dois Brasis prosperou na investigação sobre o modo de ser da socidade brasileira, para explicar as contradições de um país que nunca soube incorporar sua face retardatária, o habitante desse espaço rural, arcaico e retrógrado passou igualmente a ocupar lugar de relevância no imaginário nacional, como uma espécie de "outro" da civilização. Dessa forma, os migrantes pobres do Belo Monte se fixaram como figura emblemática da exclusão que carateriza o processo civilizatório brasileiro, daqueles que sempre ocuparam suas margens e ainda hoje erram pelo seu território em busca de terra e redenção.

Até mesmo a diversidade física ou cultural foi subsumida no uso e costume de se falar em sertão - assim mesmo, no singular -, como se não se tratasse de um espaço plural. Quer seja caatinga, semi-árido ou gerais ( "O sertão aceita todos os nomes: aqui é o Gerais, lá é o Chapadão, lá acolá é a Caatinga”. GSV, 461), o que caracteriza e define nossos sertões, para além de seus traços físicos diferenciais, é seu significado simbólico. Um vazio ainda a preencher, para o qual os projetos nacionais ainda não apresentaram respostas. Por trás da figura do sertanejo, igualmente, se projeta o homem rural brasileiro - o vaqueiro, o trabalhador sem terra, o barranqueiro, o geralista, o tropeiro - todos criados pela miséria social, que um Graciliano Ramos e um João Cabral de Melo Neto tão bem desenharam em suas vidas secas e mortes severinas. Um Brasil aterrador que Euclides já expusera e denunciara e que o romance da década de 30 iria recuperar, tematizando a tragédia coletiva do sertanejo, diante da hostilidade do meio físico e dos flagelos da natureza. O desterro, a errância, a mobilidade tornam-se condição para esses deserdados da terra, para a comunidade dos pobres de que falava Antonil, figurantes de uma história cujos protagonistas se encontra(va)m nas cidades litorâneas, nas zonas urbanas e, mais recentemente, nos gabinetes refrigerados de Brasília. 
Distante da idealização do sertão ou da gente sertaneja, portanto, que se detecta em alguns autores do século XIX e das primeiras décadas do século $\mathrm{XX},{ }^{7}$ a saga euclidiana deu outros frutos, ao inaugurar uma tradição que faria fortuna na literatura brasileira até desaguar em Grande sertão: veredas, cuja dívida para com Os sertões merece ser ainda mais detidamente demonstrada. Guimarães Rosa representaria, na perspectiva de Antonio Candido, a fase de "consciência dilacerada do subdesenvolvimento", 8 em que a realidade do subdesenvolvimento assume uma dimensão trágica e possibilita recolocar em cena, no plano literário, os efeitos do capitalismo e da modernização sobre os modos tradicionais de vida no campo. O sertão se desenha, então, como o lugar emblemático e liminar onde aflora a assimetria centro/margem e se acentuam os dilemas e as contradições do processo de desenvolvimento desigual e combinado. Numa errância típica da condição de trabalhadores livres, personagens como Manuelzão - que "seguira um movimento só, um viver sem pique nem pouso" - ou como os jagunços parecem condenados à mobilidade, ao desenraizamento, à instabilidade que marcam o modo de vida das populações rurais. Dessa forma, vaqueiros, roceiros, tropeiros, miseráveis, velhos, prostitutas, mendigos, desarrazoados, doentes deslocam-se num mundo de necessidade e carência, figuras anônimas transitando pelos Gerais, seja para buscar sua sobrevivência, seja para fugir do "estatuto de misérias e enfermidades".

Desde Sagarana até seu último livro, Rosa privilegia esse território "onde os pastos carecem de fechos" ( GSV, 9), essa zona de gado, de prática da pecuária extensiva, povoada de gente de surrão e de bordão. Penetrar no sertão roseano não é apenas uma travessia no espaço mas significa também uma viagem no tempo, em direção a um Brasil onde se confrontam o arcaico e o moderno, a fala e a letra, confronto esse encenado através da figura de um narrador letrado cuja onisciência se dissolve na incorporação de

\footnotetext{
${ }^{7}$ Refiro-me, por exemplo, a Viriato Correa, Gustavo Barroso, Afrânio Peixoto. ${ }^{8}$ ANTONIO CANDIDO, 1987.
} 
múltiplas vozes por meio do discurso indireto livre, ou através da fala em primeira pessoa de um jagunço que medeia o mundo antigo do costume e da tradição oral e o mundo letrado de um interlocutor que vem da cidade e funciona como figura vicária do leitor.

Em Guimarães Rosa, o sertanejo, nas suas mais diferentes versões, é o grande personagem, sempre apanhado na sua precária existência de absoluta penúria ou de homens suspensos entre o poder dos donos de terra e a exclusão social. Afundando pelas veredas do sertão, Riobaldo e os jagunços do bando vão cruzando com uma massa de despossuídos, dos quais os catrumanos representam, talvez, a mais simbólica tradução. Como que vinda do fundo dos tempos e das grotas, dos fundos fundos, como que estrangeiros ou outsiders em sua própria terra, essa gente de "estranhoso aspecto, só molambos de miséria”, é recebida com a seguinte resposta à pergunta de onde vinha Zé Bebelo, com seus homens e pertences:

- Ei, do Brasil, amigo! (GSV, 361)

Se o "Brasil" está em outra parte, que país é esse, tematizado como uma terra sem ordem e sem lei, um mundo de "muita doideira e pouca razão", onde civilização e barbárie não têm contornos nítidos, onde ambas estão contidas como uma coisa dentro da outra, onde se representam dramaticamente os impasses do Brasil moderno? O "Brasil", tal como pensado por Zé Bebelo, é, de fato, "outro": o desejo de reforma, o impulso modernizador em nome dos quais o Deputado move sua guerra no sertão significa, no limite, a morte simbólica do mundo dos catrumanos e também dos jagunços. Ali, em sua concepção visionária, existe um espaço virtual a ser preenchido com projetos ilustrados de progresso e benfeitorias, na perspectiva de arrancá-lo de seu atraso, que Zé Bebelo vislumbra transformar, "botando pontes, baseando fábricas, remediando a saúde de todos, preenchendo a pobreza, estreando mil escolas" ( $G S V, 122)$, no que ecoa as propostas de Euclides. A rigor, a cena emblemática desse momento de passagem é o julgamento de Zé Bebelo, que introduz o princípio do direito no mundo jagunço, 
regido pela lei do costume, ${ }^{9}$ seguida de dois outros acontecimentos climáticos, cujo resultado final será a destruição da ordem jagunça: o embate na Fazenda dos Tucanos, onde se rompe a confiança que Riobaldo deposita em Zé Bebelo, e a luta de morte entre Hermógenes e Diadorim, no Paredão.

Por sua vez, Riobaldo, instrumento de consecução dessa destruição, revisita o sertão na sua fala graças à ação da memória, que preenche estes seus vazios ( $G S V, 27)$ com os vestígios do passado. Rastros de uma vida que se recompõe pela rememoração em busca do sentido do vivido, se interroga e se reveste de um significado que escapa do plano meramente particular, material, realista. A gente viemos do inferno ( GSV, 40), conclui amargamente o velho Riobaldo, apontando para uma dimensão ao mesmo tempo real e metafísica da condição humana. É o mundo à revelia que diz simultaneamente da violência e miséria que grassam nesse espaço habitado por uma massa de excluídos e de uma ordem infernal onde Hermógenes, tigre, e assassim, reencarna a versão demonizada do sertanejo. Tratase de mais que uma mera reedição dos "valentões" de José de Alencar,

que os fazendeiros desde aquele tempo [1764] costumavam angariar para lhes formarem o séquito e guardarem sua pessoa; quando não serviam, como tantas vezes aconteceu, de cegos instrumentos a vinganças e ódios sanguinários. ${ }^{10}$

ou de figuras como o bandido José Gomes, de O Cabeleira (Franklin Távora, 1876). Na caracterização do sertanejo, se há lugar para a criação de uma imagem positiva, a sublinhar sua natureza heróica e guerreira, configura-se, por outro lado, sua demonização, já visível na imagem do seguidor de Antonio Conselheiro como "sucuri flexuosa, oculto no sombreado das tocaias", ${ }^{11}$ e que reaparece em uma personagem como

\footnotetext{
9 Ver a análise que Flávio Aguiar faz dessa cena em "O pacto e o pacto letrado". Revista Organon. Instituto de Letras da UFRGS, n. 19, p. 85-92, 1992. ${ }^{10}$ ALENCAR, 1965. v. 3, p. 858.

${ }^{11}$ Ver "A volta da serpente", de Flávio Aguiar. In: Lingua e Literatura, n. 25. São Paulo, Humanitas, 1999 (no prelo).
} 
a de Hermógenes, essa força do mal, o Judas que reinstaura a guerra e a desordem no sertão ao matar Joca Ramiro à traição.

Heróis ou bandidos, cangaceiros ou retirantes, partilham da mesma condição, seja porque, como jagunços, estão sujeitos às vicissitudes de sua vida errante, seja porque, como vaqueiros, sua vida se pauta pela perambulação permanente, seja porque, homens pobres, sem nada de seu, estão condenados a uma existência precária e instável, sempre prestes a ser tangidos da terra alheia e jogados na mais completa destituição.

Quem é pobre, pouco se apega, é um giro-o-giro no vago dos gerais, que nem os pássaros de rios e lagoas. O senhor vê: o ZéZim, o melhor meeiro meu aqui, risonho e habilidoso. Pergunto: - "Zé-Zim, por que é que você não cria galinhas-d'angola, como todo o mundo faz?" "Quero criar nada não..." - me deu resposta: - "Eu gosto muito de mudar..." (GSV, 35)

Falsa sensação de liberdade porque são vidas que, de fato, estão marcadas pela dependência. São vidas postas em disponibilidade e que desfilam sua precariedade por todo o espaço da obra roseana. O destino preso entre um político poderoso ou um fazendeiro abastado faz do jagunço e do trabalhador pobre um homem muito provisório. Na Samarra, Manuelzão, "administrador quase sócio, meio capataz de vaqueiros, certo um empregado", experimenta a dolorida consciência de sua condição em meio à festa de sagração da capelinha da fazenda e enxerga na figura do agregado Camilo a sombra da pobreza e da solidão. Na fazenda do Pinhém, o vaqueiro Lélio deve partir, ao final da narrativa, pois "seo" Senclér, após vender suas terras, irá "morar na cidade e cuidar de outros bons negócios, com a ajuda de parentes. São os nômades da monotonia", como Rosa se refere aos vaqueiros que o acompanharam na viagem ao interior de Minas Gerais, em 1952 (Tutaméia, 1962). As histórias de Rosa estão cheias deles.

Manoel Nardy é, talvez, a figura emblemática desse nomadismo. Vaqueiro, chefe de comitiva, empregado de Chico Moreira (primo do autor), Manuelzão, transfigurado no capataz e protagonista de Uma estória de amor, narra suas andanças pelos campos gerais a 
conduzir boiadas. Sob o manto de Mnemosyne, a musa da reminiscência, a sua é uma narração do destino incerto dos viventes do sertão. Uma longa vida de andanças, palmilhando os caminhos do sertão, contada no momento especial em que se cruzam experiência individual e memória coletiva. Um narrador benjaminiano, em suma, corporificado nesse viajante que traz para casa o saber das terras distantes. Uma narrativa de evocação de um tempo outro, em que o sertão também era outro, em que a paisagem sertaneja não havia sido invadida por eucaliptos, companhias carvoeiras e moto-serras, em que os sabiás, sariemas e tesoureiros ainda anunciavam chuva e não se transportavam bois em caminhão. Já com a vida vencida, o velho vaqueiro faz então um retrospecto de sua travessia pessoal e a relata para um interlocutor letrado e urbano, ${ }^{12}$ com a funda sabedoria de quem mergulhou no rio da existência, aprendeu com a beleza e o sofrimento do mundo e carrega suas cicatrizes, com os olhos voltados para o passado, revisitando os lugares da memória. Da sua fala pausada e mansa, pontuada por máximas, frases sentenciosas e causos, surge uma história de vida, permeada de imagens de um grande sertão feito de um lavarinto de veredas, uma malha de caminhos d'água que se cruzam e entrecruzam marcados pelas fileiras de buriti e pelo canto e gritos dos pássaros, mas feito também de privações, falta e destituição. Homens livres, moradores em terra alheia, empregados de fazenda, sem nada de seu, à mercê do mando de patrões e de seu arbítrio, vaqueiros como Manuelzão ou Zito (João Henrique Ribeiro), o guia e cozinheiro da comitiva, deixam o relato de uma existência precária, ainda que suas narrativas soem como um lamento por um sertão que acabou.

A precariedade é transfigurada numa bela imagem com que Manoel se define a si mesmo - um vira-folba: pépra um lado e por outro-, ao lembrar que boiadeiro não tem parada. A mesma idéia reaparece na quadrinha recolhida por Guimarães Rosa entre os vaqueiros da viagem de 52:

\footnotetext{
${ }^{12}$ Refiro-me às inúmeras entrevistas que Manoel Nardy (Manuelzão) e João Henrique Ribeiro (Zito) deram em vida a jornalistas e estudiosos da obra de Guimarães Rosa, inclusive a mim.
} 
Meu cavalo é minhas pernas, meu arreio é meu assento, meu capote é minha cama meu perigo é meu sustento. (Ave, palavra, p. 114)

Das trilhas desse sertão, percorridas por gente como Manuelzão e Zito, no entanto, permanecem registros fortes e marcantes de modos de vida mais coletivos, cujos laços de solidariedade, práticas e manifestações culturais remetem a um universo caracterizado por outros tipos de relações entre os homens do campo. São rastros, vestígios de um passado que, nostalgicamente, se rememora através de uma fala que funciona ao mesmo tempo como resgate e autobiografia. Ao narrar seu encontro com Guimarães Rosa pelos sertões de Minas em 1952, Manuelzão ressignifica esse passado, apresentando sua versão dos acontecimentos e investindo os fatos vividos de novos significados. Cheia de recorrências, silêncios e esquecimentos, essa fala ecoa a de Riobaldo, em Grande Sertão.

Tanto no plano da ficção, com Riobaldo, como no plano da História, com Manuelzão e Zito, a mesma reencenação do encontro entre o sertanejo e seu ouvinte letrado e urbano, a mesma fala divagante, sem rumo, que erra pelos caminhos da memória, o mesmo vaivém entre presente e passado, o mesmo movimento em espiral, de volutas e arabescos. Não há, na fala dos dois vaqueiros que acompanharam Rosa, a insistente indagação do ex-jagunço Riobaldo sobre o significado da vida, sobre a existência do Diabo, aquele gosto de especular idéia. Mas como ele, agora barranqueiro, já velho e de range-rede, que perscruta o passado para compreender o sentido do vivido, Manuelzão e Zito passam sua vida em revista e buscam organizar a experiência passada, através do depoimento de seu encontro decisivo com o escritor de quem mais tarde iriam se tornar personagens. Rede tecida com os fios de uma narrativa cuja chama já tênue vai consumindo a mecha da vida que ainda lhes resta, conforme nos ensina Benjamin. ${ }^{13}$

Guimarães Rosa soube pintar como poucos esses campos gerais, na sua radiografia do mundo sertanejo, onde se esboçam sua

${ }^{13}$ BENJAMIN, 1985. p. 221. 
topografia, sua paisagem e onde se produz uma verdadeira etnografia na reconstrução de um cotidiano, de modos de vida e práticas culturais e sociais. Percorre, em sua obra, toda a gama de situações que caracterizam o dia-a-dia sertanejo: doenças, violência, feitiçaria, política local, assassinatos, trabalho, festas, loucura. Nesse mundo onde tudo é e não é, se representa um país sempre já em trânsito: entre campo e cidade, entre atraso e progresso, entre arcaico e moderno. Retrato do Brasil, a obra de Rosa coloca em cena um país que erra pelas sendas da modernização, um país uno e múltiplo, rural e urbano, que corporifica, num personagem como Zé Bebelo, suas ambigüidades. Ele é o homem da Ordem e Progresso, para quem não há dúvida de que "Agora, temos de render este serviço à pátria... tudo é nacional!" ( $G S V, 101)$. Agente da modernidade, no entanto, enreda-se no atraso ao recorrer à violência para impor a lei e a paz no sertão; ao abrir mão dos seus grandes ideais para a nação para pôr em movimento a execução de uma vingança pessoal; ao renunciar à sonhada carreira política de deputado para acabar no comércio.

Na obra de Rosa, o sertão se abre, se cinde em múltiplas veredas, em uma rede de caminhos, povoados por personagens sempre em trânsito, em um vaivém constante, e ali se combinam, se entrelaçam, convivem e se confrontam, de certo modo, as diferentes leituras que tanto os escritores como os diversos intérpretes do Brasil ofereceram dessa região: ora o sertão representa a força primitiva de uma região ainda marcada pela resistência ao moderno e imersa na tradição; ora, em sinal invertido, o sertão preserva algo da gênese da nação, como um lugar fundador na cena imaginária da nacionalidade; ora o sertão encena os limites entre os dois Brasis, emprestando à nossa modernidade feições de contraponto e contraste.

A inauguração de Brasília em 1960 concretizou o longamente adiado projeto de construir uma capital no interior do Brasil, que surgira pela primeira vez proposto por José Bonifácio na Constituinte de 1823 e fora enfim previsto pela Constituição Republicana, como parte do esforço de integração do interior e difusão do progresso. Missões civilizatórias haviam sido organizadas pela República, com a finalidade de incorporar os sertões, compreendidos como fisionomia 
particular da nacionalidade, a ser descobertos e desbravados. As viagens ao interior, realizadas por geólogos, engenheiros, militares e cientistas, a campanha de saneamento rural objetivavam mapear, estudar, submeter a escrutínio e, no limite, intervir nessas regiões, embora pareça que o sertão lhes tenha sempre escapado, eludido. Por sua vez, a nova capital brasileira, construída como um marco da arquitetura moderna, plantada no Planalto Central como um gesto de conquista desse espaço indomado e inculto, vai sendo sempre já cercada pelo sertão: ${ }^{14}$ "Sertão é isso: o senhor empurra para trás, mas de repente ele volta a rodear o senhor dos lados. Sertão é quando menos se espera”. ( $G S V, 204)$

Diferentemente de Riobaldo, que carece de ir ponteando opostos, o Brasil é um mundo muito misturado e, como o sertão, é o "lugar do atraso e do progresso imbricados, do arcaico e do moderno enredados, onde o movimento do tempo e das mudanças históricas compõe as mais peculiares combinações". ${ }^{15}$

Se a simples oposição entre sertão atrasado e litoral progressista já não dá conta de explicar o Brasil - basta atentar para os bolsões de pobreza nas periferias urbanas e os enclaves de riqueza e progresso nas áreas rurais e interioranas - ainda assim esses contrastes se fazem ouvir num neologismo como Belíndia, cunhado para referir esse impasse que nos constitui. Os caminhos da modernidade parecem ainda mais complexos e tortuosos. Sertão e metrópole se entranham e se fundem, como faces de uma mesma moeda. A Favela desceu os morros de Canudos e ocupou os do Rio de Janeiro, os deserdados da terra ou rondam as periferias dos grandes centros ou perambulam pelas estradas, e os sertanejos fazem a festa na Praça Sílvio Romero em São Paulo, se apropriando dos espaços urbanos. Sem pretender

${ }^{14}$ Parece ser isso o que Nelson Pereira dos Santos pretende mostrar, em sua adaptação de quatro contos de Primeiras Estórias no filme "A Terceira Margem do Rio", de 1994. Sobre o filme, o diretor diz: "Talvez a terceira margem do rio seja o que todo o mundo procura e não sabe o que é. Quis mostrar que talvez exista uma terceira margem para o Brasil, entre o velho e o novo".

15 ARRIGUCCI, 1994. p. 17. 
fazer troça, a profecia de Antonio Conselheiro, ${ }^{16}$ não tendo se cumprido, poderia se repropor hoje, em um novo acerto de contas com a realidade, como o sertão (ao menos uma parte dele) virou cidade e a cidade virou sertão.

Como Riobaldo, que se lança, ao narrar sua história, em "peregrinação errante num labirinto desencantado que é o mundo moderno, o mundo sem Diadorim", ${ }^{17}$ o Brasil também erra pelos (des)caminhos da modernidade, sempre em trânsito entre a soberania e a dependência, a letra e a fala, o arcaico e o moderno. Travessia sem rumo, destino incerto? Onde o projeto de nação? Onde o Brasil autêntico, que se acreditava encontrar-se no interior do país? Passados cem anos da imortalização do sertanejo como a rocha viva da nossa raça, o cerne de uma nacionalidade, os exilados em sua própria pátria dos dias de hoje continuam a perambular por estradas e caminhos em busca de redenção e ainda vigoram o apelo de Euclides da Cunha pela incorporação dos rudes patríciosà existência política e a conclamação de Afonso Arinos para que essa força seja incorporada à nacionalidade.

Tendo por destino a estrada e o rio, as personagens roseanas vagam em busca de algo, em permanente movimento, simbolicamente reencenando, no plano do imaginário, a vida errante dos habitantes do Brasil real, onde o passado é ainda presente, o presente é futuro e o futuro se projeta como um tempo que nunca chega. Se Riobaldo é "o homem desterrado de sua verdadeira pátria, errante numa travessia solitária, sem retorno possível", ${ }^{18}$ o país também se encontra em travessia, navegando entre o velho e o novo, como um destino em aberto, como uma promessa não cumprida.

\footnotetext{
${ }^{16}$ Em Os sertôes, a profecia do Conselheiro está registrada como tendo sido "Então, o sertão virará praia e a praia virará sertão", sendo que praia naquela região se refere às "manchas de solo mais fértil circundadas pela terra calcinada circundante". In: GALVÃO, 2000. p. 45.

${ }^{17}$ ARRIGUCCI, 1994. p. 28.

18 ARRIGUCCI, 1994. p. 29.
} 


\section{Referências Bibliográficas}

ALENCAR, José. O sertanejo. In: Obra completa. Rio de Janeiro: Aguilar, 1965. v. 3.

ARRIGUCCI Jr., Davi. O mundo misturado. Romance e experiência em Guimarães Rosa. Novos Estudos CEBRAP, São Paulo, n. 40, p. 7-29, nov.1994.

BENJAMIN, Walter. O narrador. Considerações sobre a obra de Nikolai Leskov. In: Magia e técnica, arte e política. São Paulo: Brasiliense, 1985. p.197-221.

BERNUCCI, Leonardo. O bicho-preguiça da fábula. In: $A$ imitação dos sentidos. Prógonos, contemporâneos e epígonos de Euclides da Cunha. São Paulo: Edusp, 1995. p. 85-98.

BRAIT, Beth (Org.). O sertão e os sertões. São Paulo: Arte \& Ciência, 1998.

BRANDÃO, Carlos Rodrigues. Memória/Sertão. São Paulo: Editorial ConeSul/ Ed. UNIUBE, 1998.

CANDIDO, Antonio. Literatura e subdesenvolvimento. In: A educação pela noite e outros ensaios. São Paulo: Ática, 1987. p. 140-162.

CORTESÃO, Jaime (Adap.). A carta de Pero Vaz de Caminha- Primeiro relato oficial sobre a existência do Brasil. [s.1.]: Empresa Folha da Manhã, 1999.

FINAZZI-AGRÒ, Ettore. Um lugar do tamanho do mundo: tempos e espaços da ficção em João Guimarães Rosa. Belo Horizonte: Ed. UFMG, 2001.

GALVÃO, Walnice Nogueira. Anotações à margem do regionalismo. Literatura e Sociedade, São Paulo, n. 5, p. 44-55, 2000.

. As formas do falso. Um estudo sobre a ambigüidade no Grande sertão: veredas. São Paulo: Perpectiva, 1972.

. Guimarães Rosa. São Paulo: Publifolha, 2000.

. De sertões e jagunços. In: Sacos de gatos. Estudos críticos. 2. ed. São Paulo: Duas Cidades, 1976. p. 65-85.

GRANATO, Fernando. Nas trilhas do Rosa. Uma viagem pelos caminhos de Grande sertão: veredas. São Paulo: Scritta, 1996.

LIMA, Nísia Trindade. Um sertão chamado Brasil. Rio de Janeiro: Renavan/ IUPERJ, UCAM, 1999.

LORENZ, Gunter W.; ROSA, João Guimarães. Literatura deve ser vida - um diálogo de GWL e JGR (Gênova, janeiro de 1965). In: Exposição do novo livro alemão no Brasil, 1971. 
OLIVEIRA, Franklin. Euclydes: A espada e a letra. Rio de Janeiro: Paz e Terra, 1983.

PROENÇA, Manoel Cavalcanti. Ribeira do S. Francisco. Rio de Janeiro: Gráfica Laemmert, [1944].

SUASSUNA, Ariano. A pedra do reino. Rio de Janeiro: José Olympio, 1973.

TÁVORA, Frankin. O Cabeleira. São Paulo: Ática, 1977.

VENTURA, Roberto. Visões do deserto: selva e sertão em Euclides da Cunha. In: BRAIT, Beth (Org.). O sertão e os sertões. São Paulo: Arte \& Ciência, 1998. p. 65.

\section{Resumo}

Este artigo pretende percorrer os sentidos de sertão e sertanejo, tal como foram construídos no âmbito da literatura brasileira, pensando-os como emblemas de visões de nação e nacionalidade e propondo-os como sentidos que convivem e se confrontam na obra de João Guimarães Rosa. Busca ainda, destacando algumas semelhanças entre duas falas (a de Riobaldo, no plano ficcional, e a de Manuelzão, no plano histórico), discutir como a memória desempenha um papel fundamental na construção daqueles sentidos.

\section{Abstract}

This article intends to explore the meanings of sertão and sertanejo as they have been constructed within Brazilian Literature, considering them as emblems of visions of nation and nationality and proposing them as meanings which exist and confront one another in the works of João Guimarães Rosa. By pointing out some similarities between two discourses (Riobaldo's, on the fictional level, and Manuelzão's, on the historical one), it seeks to discuss how memory plays a central role in the construction of those meanings. 